\title{
RESTIO HOOKERI (RESTIONACEAE), A NEW NAME FOR A FAMILIAR TASMANIAN SPECIES, AND REINSTATEMENT OF GAHNIA RODWAYI F.MUELL. EX RODWAY (CYPERACEAE)
}

\author{
by D.I. Morris
}

Restio hookeri sp.nov, a new species endemic in Tasmania, is described and compared with the closely related species $R$. monocephalus R.Br. with which it has been confused for many years. Gahnia rodwayi F. Muell. ex Rodway is reinstated to replace the later name $G$. graminifolia.

Key Words: Tasmania, Restio, Restionaceae, Gahnia, Cyperaceae.

In BANKS, M.R. et al. (Eds), 1991 (31:iii): ASPECTS OF TASMANIAN BOTANY — A TRIBUTE TO WINIFRED CURTIS. Roy. Soc. Tasm. Hobart: 33-34. https://doi.org/10.26749/rstpp.124.2.33

\section{INTRODUCTION}

Since the publication of Hooker's Flora Tasmaniae in 1858 two species of Restio endemic in Tasmania have been confused:

(1) Species A-Restio monocephalus R.Br. has culms bearing a single leaf-sheath (or very rarely two sheaths), the apex of the sheath produced into two short erect auricles separated by a reduced lamina. The inflorescence consists of one or, more rarely, two spikelets and the glumes are glabrous with narrow membranous margins. At BM, a specimen labelled in Brown's handwriting "1 Restio monocephalus in ericetis inter Baie du Nord Oest \& Fl. Derwent Apr 1804" was annotated as holotype by L.A.S. Johnson in 1963.

(2) Species B - the culms bear several leaf-sheaths with obtuse, woolly-hairy apices. The inflorescence is a raceme or reduced panicle with up to $20(-27$ ?) spikelets or, more rarely, a single spikelet, the glumes woolly-hairy at the apex and sometimes also on the dorsal surface below the apex.

Confusion began when Hooker (1858) combined the characters of both species in his description of $R$. monocephalus. Fitch's illustration (t. CXXXV) is of a specimen of species B, probably collected by Milligan at Macquarie Harbour.

Mueller (1873) saw only specimens of species B (Stuart, Southport and Milligan "sine notacione"). He accepted these as being $R$. monocephalus but, because they always bore more than one and "up to 27 " spikelets per culm, he considered Brown's epithet inappropriate, "quare nomen specificum mutare audeo" and created the name $R$. oligocephalus, placing $R$. monocephalus in synonymy.

Rodway (1894) noticed the differences between species $\mathrm{A}$ and $\mathrm{B}$, and, considering species $\mathrm{A}$ to be a variety of species $\mathrm{B}$, created $F$. oligocephalus var. glabrum.

Johnson \& Briggs (1986) raised Rodway's var. glabrum to specific rank as $R$. glaber.

Species B has no validly published name. Mueller's statement that he "ventured" to change Brown's epithet and his placing $R$. monocephalus in synonymy makes $R$. oligocephalus a superfluous and therefore illegitimate name. $R$. glaber L.A.S. Johnson \& B. Briggs is similarly illegitimate.

The concepts of the various authors may be shown as below:
Species A

Species B

unknown to Brown

\section{R. monocephalus}

$R$. oligocephalus (syn. R. monocephalus)

\section{R. oligocephalus}

var. glabrum

Brown (1810)

Mueller (1873)

Rodway (1894)

Johnson \& Briggs (1986)

Morris (this paper)
R. glaber

$R$. monocephalus
$R$. oligocephalus var. oligocephalus (syn. R. mono cephalus)

$R$. monocephalus

$R$. hookeri 


\section{TAXONOMY}

\section{Restio hookeri D. Morris, sp.nov.}

Differt a R. monocephalo R.Br. statura elatiore, culmis vaginis foliorum pluribus apicibus obtusis lanatis, inflorescentis spiculis pluribus et marginibus glumarum lanatis.

\section{Typus}

Tasmania: sandy heath on sandstone, Longley, D.I. Morris 86423, 2.iv.1990. Holotypus: HO 122237. Isotypi: $\mathrm{AD}, \mathrm{CBG}, \mathrm{CANB}, \mathrm{MEL}, \mathrm{NSW}, \mathrm{BOL}$.

\section{Description}

Rhizome horizontal, up to $0.2 \mathrm{~m}$ long, up to $6 \mathrm{~mm}$ diameter, internodes hairy, scales broad. Culms $0.7-$ $0.49(-1.1) \mathrm{m}$ tall, $0.75-1.75 \mathrm{~mm}$ diameter; leaf-sheaths up to $20 \mathrm{~mm}$ long, loosely clasping below, spreading to \pm patent in the upper half; apex obtuse, shortly and bluntly mucronate, woolly-hairy, rapidly weathering. Inflorescence a raceme, reduced panicle or reduced to a solitary spikelet, bearing 1-20(-27?) spikelets. Male and female spikelets similar, ovoid to subspherical; male spikelets, $7-8.5 \mathrm{~mm}$ long, several-flowered; female spikelets 6-7 mm long, several to few-flowered, sometimes reduced to 1 or 2 terminal flowers; spikelets of both sexes often with basal glumes empty, glumes 3-5 mm long, imbricate, obtuse to acute, margins woolly-hairy at the apex, sometimes with a cluster of woolly hairs below the apex; flowers compressed, perianth segments $6, \pm$ equalling the glume, lanceolateelliptic; the two lateral outer segments conduplicate, keels woolly-ciliate. Male flowers with 3 stamens, anthers exserted, c. $2 \mathrm{~mm}$ long. Female flowers with 3 staminodes, c. $2.5 \mathrm{~mm}$ long, styles 2 , joined at the base. Capsule c. $3 \mathrm{~mm}$ long, flattened, 2-locular, dehiscing along the thickened margins, style-bases persistent, curved. Seed not seen; most mature capsules empty or filled with a black fungal mass.

\section{Distribution}

Tasmania: North West, East Coast, South West, West Coast (regions as Orchard 1988) — heath and sedgeland on sandy or peaty soils, near sea level to about $1000 \mathrm{~m}$ altitude.

\section{Specimens Examined (selection only)}

Tasmania: North West - A.M. Buchanan 91101 (HO 103687); R.C. Gunn s.n. (HO 65508). West Coast P. Collier 4414 (HO 119836); A. Moscal 4890 (HO 89930). South West - B.G. Briggs 8245 (HO 113964); J. Milligan s.n. (HO 65501). East Coast - M. Allan s.n. (HO 37343); R.C. Gunn s.n. (HO 65506). [Further details of specimens listed in this paper, e.g. collecting site and date, are available from the Herbaria noted or from the Royal Society of Tasmania Library (Archives), GPO Box 1166M, Hobart, Tasmania, Australia 7001. $E d$.

\section{Etymology}

Named for J.D. Hooker who first described the species, with an illustration by Fitch.

\section{Gahnia rodwayi F. Muell ex Rodway}

In 1893, Rodway validly published the name of a new species, Gahnia rodwayi F. Muell. ex Rodway. In 1894, he published a second name for the same species, Gahnia graminifolia Rodway, saying "For various reasons I have preferred to change its name". Since the earlier name has precedence, $G$. graminifolia is superfluous and a nomen illegitimum and the correct name is Gahnia rodwayi F.Muell. ex Rodway.

\section{ACKNOWLEDGEMENTS}

I wish to express my thanks to Dr T.D. Macfarlane, Australian Botanical Liaison Officer at Kew, who kindly examined specimens at Kew and the British Museum, and to Dr A.E. Orchard, Tasmanian Herbarium, for suggestions on the text.

\section{REFERENCES}

BROWN, R., 1810: PRODROMUS FLORAE HOLLANDIAE ET INSULAE VAN-DIEMEN. J. Johnson, London: 245.

HoOKER, J.D., 1858: FLORA TASMANIAE II: t. CXXXV. Lovell Reeve \& Co., London.

Johnson, L.A.S. \& Briggs, B.G., 1986: A new species and a new genus of Restionaceae from Tasmania. Telopea 2(6): 737-740.

Mueller, F., 1873: FRAGMENTA VIII. Govt Printer, Melbourne: 68 .

ORCHARD, A.E., 1988: A natural regions map for Tasmania. Pap. Proc. R. Soc. Tasm. 122: 47-51.

Rodway, L., 1893: Notes on some plants new to Tasmania. Pap. Proc. R. Soc. Tasm. 1892: 92-93.

Rodway, L., 1894: Botanical notes. Pap. Proc. R. Soc. Tasm. 1893: $179-187$.

(accepted 10 August 1990)

D.I. Morris

Tasmanian Herbarium, GPO Box 252C, Hobart, Tasmania, Australia 7001 